\title{
Introduction to Hamilton-Wentworth District School Board Assessment and Evaluation Guildelines
}

\section{Lawrie Cook}

I n The Hamilton-Wentworth District School Board the major initiatives for Secondary School Reform are overseen by system committees. Our system Assessment and Evaluation Committee includes administrators, consultants and teachers. This committee is supported by an Assessment and Evaluation Committee within each school. The school committees include a teacher from each subject area, a member of the system committee and at least one administrator.

Last spring the system committee created a set of Assessment and Evaluation Implementation Guidelines for these committees to use to help guide teachers and departments through all the stages of implementation of new assessment and evaluation policies. We used our knowledge of the provincial assessment and evaluation project Policy to Practice: Implementation Support for the Provincial Secondary Assessment Policy to create guidelines that would help teachers translate provincial policy into classroom practices.

We just provided in-service to all of our school Assessment and Evaluation Committees on the use of these implementation guidelines. They are being used by these committees, individual departments and the school improvement planning team to identify "next steps' in the implementation of assessment and evaluation reforms within each secondary school.

\section{Implementation Timelines}

The dates given here show implementation for each grade without the transfer of learning from one grade to the next. It is recognized that with each successive grade the implementation schedule will condense as learning acquired in early implementation of the intermediate grades is transferred to the implementation of the senior grades. *Full implementation of Grades 11 and 12 should be less than indicated here.

\begin{tabular}{|c|c|c|c|c|c|}
\hline & Awareness & $\begin{array}{c}\text { Beginning } \\
\text { Implementation }\end{array}$ & Partial Implementation & Full Implementation & Consolidation \\
\hline Grade 9 & 1999 & $1999-2000$ & $2000-2001$ & $2001-2002$ & $2002-2003$ \\
\hline Grade 10 & $1999-2000$ & $2000-2001$ & $2001-2002$ & $2002-2003$ & $2003-2004$ \\
\hline Grade 11* & $2000-2001$ & $2001-2002$ & $2002-2003$ & $2003-2004$ & $2004-2005$ \\
\hline Grade 12* & $2001-2002$ & $2002-2003$ & $2003-2004$ & $2004-2005$ & $2005-2006$ \\
\hline
\end{tabular}

continued on pg. 16

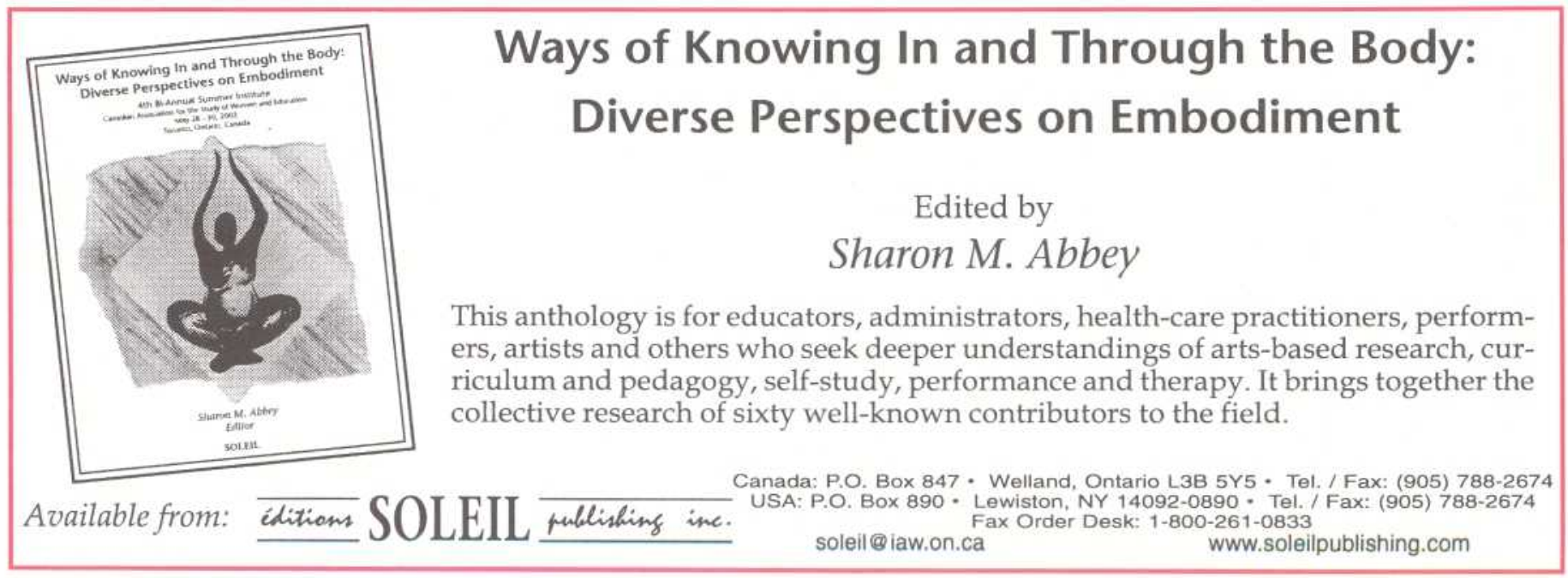


Hamilton-Wentworth District School Board ASSESSMENT AND EVALUATION IMPLEMENTATION GUIDELINES

\begin{tabular}{|c|c|c|c|c|}
\hline $\begin{array}{l}\text { POLICY } \\
\text { General Policy } \\
\text { Statements }\end{array}$ & & $\begin{array}{l}\text { CLASSROOM PRACTICES } \\
\text { Expectations for teachers } \\
\text { and students }\end{array}$ & RESOURCES/SUPPORTS & INDICATORS \\
\hline \multirow{5}{*}{$\begin{array}{l}\text { Assessment and evaluation } \\
\text { will be based on the provin- } \\
\text { cial curriculum expectations } \\
\text { (content standards) and the } \\
\text { achievement levels (perfor- } \\
\text { mance standards) }\end{array}$} & AWARENESS & $\begin{array}{l}\text { - OSS and curriculum documents and course pro- } \\
\text { files are studied } \\
\text { - identification of expectations and achievement } \\
\text { charts } \\
\text { - analysis of expectations to determine differences } \\
\text { from previous curriculum } \\
\text { PROGRAM PLANNING AND ASSESSMENT } \\
\text { document studied }\end{array}$ & $\begin{array}{l}\text { - Subject-specific training } \\
\text { - SIT Training, Phases I-III }\end{array}$ & $\begin{array}{l}\text { - new documents in evidence } \\
\text { SIT team providing PD } \\
\text { - Some schools piloting Provincial } \\
\text { Report Card } \\
\text { - exploring research and resources }\end{array}$ \\
\hline & $\begin{array}{l}\text { BEGINNING } \\
\text { IMPLEMENTATION }\end{array}$ & $\begin{array}{l}\text { - assessment strategies are linked to curriculum } \\
\text { expectations } \\
\text { - understanding of differences between assess- } \\
\text { ment and evaluation } \\
\text { - teachers provide students with specific feedback } \\
\text { to improve learning }\end{array}$ & $\begin{array}{l}\text { - Subject-specific workshops } \\
\text { - Phases III - IV } \\
\text { Report card comment writing } \\
\text { workshop } \\
\text { - Exemplar (Phase V) in-services } \\
\text { - Curriculum writing consortium } \\
\text { in-service for writers }\end{array}$ & $\begin{array}{l}\text { - using profiles, documents and } \\
\text { achievement charts } \\
\text { - using different strategies for as- } \\
\text { sessment and evaluation } \\
\text { providing feedback on all assess- } \\
\text { ments }\end{array}$ \\
\hline & $\begin{array}{c}\text { PARTIAL } \\
\text { IMPLEMENTATION }\end{array}$ & $\begin{array}{l}\text { - assessment strategies are developed reflecting } \\
\text { new strands/units and assessment and evalua- } \\
\text { tion } \\
\text { use of a variety of assessment and evaluation } \\
\text { strategies } \\
\text { - assessment and evaluation criteria are given to } \\
\text { students prior to commencing evaluations } \\
\text { feedback focuses on student progress and } \\
\text { achievement of curriculum expectations to im- } \\
\text { prove student learning } \\
\text { diagnostic and formative assessments used } \\
\text { use of the design-down process in strand/unit } \\
\text { planning using profiles and CUP units as tem- } \\
\text { plates }\end{array}$ & $\begin{array}{l}\text { - introduction of Grade } 11 \text { curricu- } \\
\text { lum from consortium } \\
\text { - Subject-specific training } \\
\text { - CUP in-services } \\
\text { - in-service for administrators } \\
\text { - staff in-services for AER } \\
\text { - Brochures\# } 1 \text { - } 3 \\
\text { - Culminating Activities in-services } \\
\text { (Phase VII) } \\
\text { - Subject AER workshops and } \\
\text { in-services } \\
\text { - Exemplar field testing }\end{array}$ & $\begin{array}{l}\text { - use of CUP units and course pro- } \\
\text { files } \\
\text { - begin using new report card com- } \\
\text { ment bank } \\
\text { - assessment criteria given with as- } \\
\text { signments } \\
\text { - use of exemplars } \\
\text { - distinction between formative and } \\
\text { summative activities } \\
\text { - feedback becoming more specific } \\
\text { - begin using culminating activities } \\
\text { and/or RPTs } \\
\text { - assessments identified with expec- } \\
\text { tations }\end{array}$ \\
\hline & $\begin{array}{c}\text { FULL } \\
\text { IMPLEMENTATION }\end{array}$ & $\begin{array}{l}\text { - assessment and evaluation are monitored sepa- } \\
\text { rately } \\
\text { - a variety of assessment strategies that use higher } \\
\text { order thinking skills (Bloom's taxonomy) } \\
\text { diagnostic and formative assessments not used } \\
\text { in evaluation } \\
\text { - feedback includes a variety of methods, e.g., stu- } \\
\text { dent-teacher conferences, anecdotal comments, } \\
\text { peer/self assessment } \\
\text { - identification of key learnings and alignment of } \\
\text { curriculum to emphasize these } \\
\text { - course planning uses key learnings and the de- } \\
\text { sign-down process } \\
\text { changes to assessment and evaluation practices } \\
\text { made to accommodate individual student needs }\end{array}$ & $\begin{array}{l}\text { - Subject-specific training } \\
\text { - Exemplar field testing } \\
\text { - Phase VHI } \\
\text { - Brochure \# } 5 \text { in-service } \\
\text { - Phase IX } \\
\text { Subject/departmental plans }\end{array}$ & $\begin{array}{l}\text { - separate recording of assessments } \\
\text { and evaluations } \\
\text { - assessment activities include anal- } \\
\text { ysis, synthesis and evaluation } \\
\text { only summative activities used to } \\
\text { calculate marks } \\
\text { - records for peer \& self-assessments } \\
\text { and student- teacher conferences } \\
\text { - use of overall expectations and/or } \\
\text { key learnings to plan culminating } \\
\text { activities } \\
\text { - summative evaluation includes } \\
\text { culminating activities } \\
\text { - use of Rich Performance Tasks } \\
\text { propriate to IEP }\end{array}$ \\
\hline & CONSOLIDATION & $\begin{array}{l}\text { - review of courses } \\
\text { - identification of areas for personal growth } \\
\text { (Teacher Action Plan/Annual Learning Plan) }\end{array}$ & & $\begin{array}{l}\text { - Grade } 9 \text { curriculum, assessments } \\
\text { and evaluations revised as re- } \\
\text { quired }\end{array}$ \\
\hline
\end{tabular}




\begin{tabular}{|c|c|c|c|c|}
\hline $\begin{array}{c}\text { POLICY } \\
\text { General Policy Statements }\end{array}$ & & $\begin{array}{l}\text { CLASSROOM PRACTICES } \\
\text { Expectations for teachers and students }\end{array}$ & $\begin{array}{l}\text { RESOURCES/ } \\
\text { SUPPORTS }\end{array}$ & INDICATORS \\
\hline \multirow[b]{2}{*}{$\begin{array}{l}\text { Assessment and evaluation } \\
\text { will be based on the provin- } \\
\text { cial curriculum expectations } \\
\text { (content standards) and the } \\
\text { achievement levels (perfor- } \\
\text { mance standards) }\end{array}$} & AWARENESS & $\begin{array}{l}\text { - achievement charts in curriculum documents are stud- } \\
\text { ied } \\
\text { - analysis of four categories to determine differences } \\
\text { from previous curriculum } \\
\text { - PROGRAM PLANNING AND ASSESSMENT docu- } \\
\text { ment studied }\end{array}$ & $\begin{array}{l}\text { - Subject-specific training } \\
\text { - SIT Training, Phases I - III }\end{array}$ & $\begin{array}{l}\text { - new documents in evidence } \\
\text { - SIT team providing PD } \\
\text { - exploring research and resources }\end{array}$ \\
\hline & $\begin{array}{c}\text { BEGINNING } \\
\text { IMPLEMENTATION }\end{array}$ & $\begin{array}{l}\text { - teaching and learning linked to expectations in all four } \\
\text { categories } \\
\text { - use of levels of achievement given in charts to identify } \\
\text { the level at which the student has achieved the expecta- } \\
\text { tions } \\
\text { - use of four categories for assessment for some } \\
\text { tasks/performances } \\
\text { - use of the achievement chart to guide instruction, as- } \\
\text { sessment and evaluation } \\
\text { - use of criterion-referenced assessment rather than } \\
\text { norm-referenced }\end{array}$ & $\begin{array}{l}\text { - Subject-specific work- } \\
\text { shops } \\
\text { - Phases III - IV } \\
\text { - Report card comment } \\
\text { writing workshop } \\
\text { - Exemplar (Phase V) } \\
\text { in-services }\end{array}$ & $\begin{array}{l}\text { - using documents and achievement } \\
\text { charts } \\
\text { - assessing using levels } \\
\text { - initial use of rubrics } \\
\text { - asing four categories in assessment } \\
\text { - planning with the Achievement Chart } \\
\text { - assessing with curriculum standards }\end{array}$ \\
\hline $\begin{array}{l}\text { Assessment and evaluation } \\
\text { must be based on the catego- } \\
\text { ries of knowledge and skills } \\
\text { and the achievement level de- } \\
\text { scriptions given in the } \\
\text { Achievement Chart }\end{array}$ & $\begin{array}{c}\text { PARTIAL } \\
\text { IMPLEMENTATION }\end{array}$ & $\begin{array}{l}\text { - use of the achievement chart as the framework for in- } \\
\text { struction, assessment, evaluation and reporting } \\
\text { use of a variety of assessment strategies to address the } \\
\text { different categories } \\
\text { use of the achievement chart as the framework for pro- } \\
\text { viding feedback to students for improvement } \\
\text { subject council clarification of the weightings of the } \\
\text { four categories of knowledge and skills (in each curric- } \\
\text { ulum document these may differ in focus and intent) } \\
\text { - use of the exemplar documents as a resource to assist } \\
\text { making consistent, professional judgements about the } \\
\text { quality of student work by achievement chart catego- } \\
\text { ries and levels } \\
\text { planning and instruction so that the amount of instruc- } \\
\text { tional time and types of learning opportunities corre- } \\
\text { spond to the emphasis of the curriculum expectations } \\
\text { and the suggested category weightings if the Achieve- } \\
\text { ment Chart }\end{array}$ & $\begin{array}{l}\text { - introduction of Grade } 11 \\
\text { curriculum from consor- } \\
\text { tium } \\
\text { - Subject-specific training } \\
\text { - CUP in-services } \\
\text { - Staff in-services for AER } \\
\text { - Culmures\# 1 - } \\
\text { in-services (Phase VII) } \\
\text { - Subject AER workshops } \\
\text { - Exd in-services } \\
\text { - Exemplar field testing }\end{array}$ & $\begin{array}{l}\text { - use of the four categories in planning } \\
\text { for instruction (lesson and/or unit } \\
\text { plans) } \\
\text { - use of different instructional strate- } \\
\text { gies to address different categories } \\
\text { - use of different assessment strategies } \\
\text { to address different categories } \\
\text { - use of rubrics for Rich Performance } \\
\text { Tasks } \\
\text { - feedback to students addresses } \\
\text { achievement in the four categories in- } \\
\text { cluding next steps } \\
\text { consistent outlines for assessment in } \\
\text { all subject areas } \\
\text { use of exemplars } \\
\text { use of a variety of teaching and assess- } \\
\text { ment strategies that are consistent } \\
\text { with the weightings developed by } \\
\text { subject councils }\end{array}$ \\
\hline \multirow[t]{2}{*}{$\begin{array}{l}\text { The percentage grade repre- } \\
\text { sents the quality of the stu- } \\
\text { dent's overall achievement of } \\
\text { the course and the corre- } \\
\text { sponding level of achieve- } \\
\text { ment as describes in the } \\
\text { Achievement Chart }\end{array}$} & $\begin{array}{c}\text { FULL } \\
\text { IMPLEMENTATION }\end{array}$ & $\begin{array}{l}\text { - linking some curriculum expectations (overall expecta- } \\
\text { tions) to more than one achievement chart category at } \\
\text { different times in the course } \\
\text { - gather samples of student work form a course and used } \\
\text { to model what achievement looks like at each of the } \\
\text { four levels } \\
\text { - where appropriate, addressing all four categories when } \\
\text { designing culminating activities/performance tasks } \\
\text { - identification of key learnings and alignment of assess- } \\
\text { ment and evaluation to emphasize these } \\
\text { - assessment and evaluation allow students to revisit key } \\
\text { expectations throughout the course }\end{array}$ & $\begin{array}{l}\text { - Subject-specific training } \\
\text { - Pxemplar field testing। } \\
\text { - Phase VIII } \\
\text { - Subject/departmental } \\
\text { plans }\end{array}$ & $\begin{array}{l}\text { - clustering of specific expectations to } \\
\text { support key learnings } \\
\text { - inter-subject comparison of categories } \\
\text { - development of rubrics in consultation } \\
\text { with students } \\
\text { - evaluation of overall expectations, } \\
\text { some using more than one of the cate- } \\
\text { gories } \\
\text { - samples of student work in evidence } \\
\text { tasks of rubrics to assess performance }\end{array}$ \\
\hline & CONSOLIDATION & $\begin{array}{l}\text { - review of courses } \\
\text { identification of areas for personal growth (Teacher Ac- } \\
\text { tion Plan/Annual Learning Plan) }\end{array}$ & & $\begin{array}{l}\text { - all course evaluations consistent with } \\
\text { subject council weighing of categories }\end{array}$ \\
\hline
\end{tabular}




\begin{tabular}{|c|c|c|c|c|}
\hline $\begin{array}{c}\text { POLICY } \\
\text { General Policy Statements }\end{array}$ & & $\begin{array}{c}\text { CLASSROOM PRACTICES } \\
\text { Expectations for teachers and students }\end{array}$ & $\begin{array}{l}\text { RESOURCES/ } \\
\text { SUPPORTS }\end{array}$ & INDICATORS \\
\hline \multirow[t]{2}{*}{$\begin{array}{l}\quad 70 \% / 30 \% \\
\text { The final percentage grade } \\
\text { for Grade } 9-12 \text { courses will } \\
\text { be derived as follows: }\end{array}$} & AWARENESS & $\begin{array}{l}\text { - OSS, curriculum documents and course profiles } \\
\text { are studied } \\
\text { - PROGRAM PLANNING AND ASSESSMENT doc- } \\
\text { ument studied }\end{array}$ & $\begin{array}{l}\text { - Subject-specific training } \\
\text { - SIT Training, Phases I - III }\end{array}$ & $\begin{array}{l}\text { - new documents in evidence } \\
\text { - SIT team providing PD }\end{array}$ \\
\hline & $\begin{array}{l}\text { BEGINNING } \\
\text { IMPLEMENTATION }\end{array}$ & $\begin{array}{l}\text { - teaching/learning strategies are linked to evalua- } \\
\text { tion strategies } \\
\text { - } 70 \% \text { of final grade based on course work }\end{array}$ & $\begin{array}{l}\text { - Subject-specific workshops } \\
\text { - Phases III - IV } \\
\text { Report card comment } \\
\text { writing workshop } \\
\text { - Exemplar (Phase V) in-ser- } \\
\text { vices }\end{array}$ & $\begin{array}{l}\text { - course outlines modified to reflect } 70 / \\
30 \% \\
\text { - using different strategies for assessment } \\
\text { and evaluation } \\
\text { - providing feedback on all assessments }\end{array}$ \\
\hline $\begin{array}{l}\text { Thirty per cent of the grade } \\
\text { will be based on a final evalu- } \\
\text { ation in the form of an exami- } \\
\text { nation, performance, essay, } \\
\text { and/or other method of eval- } \\
\text { uation suitable to the course } \\
\text { content and administered to- } \\
\text { wards the end of the course. } \\
\text { Seventy per cent of the grade } \\
\text { will be based on evaluations } \\
\text { conducted throughout the } \\
\text { course. This portion of the } \\
\text { grade should reflect the stu- } \\
\text { dent's most consistent level } \\
\text { of achievement throughout } \\
\text { the course, although special } \\
\text { consideration should be } \\
\text { given to the more recent evi- } \\
\text { dence of achievement. }\end{array}$ & $\begin{array}{c}\text { PARTIAL } \\
\text { IMPLEMENTATION }\end{array}$ & $\begin{array}{l}\text { - assessment and evaluation outlines are given to } \\
\text { students to make them aware of how the grade } \\
\text { will be determined } \\
\text { - use of a variety of assessment and evaluation } \\
\text { strategies throughout the course to determine the } \\
70 \% \\
\text { - assessment and evaluation criteria are given to } \\
\text { students prior to commencing evaluations } \\
\text { - diagnostic and formative assessments used } \\
\text { throughout the course } \\
\text { - assessment and evaluation based on sufficient evi- } \\
\text { dence in each of the four categories } \\
\text { - use of this evidence in each of the categories to de- } \\
\text { termine } 70 \% \text { if the final grade } \\
30 \% \text { summative form more that a single, one-time } \\
\text { evidence } \\
\text { - } 30 \% \text { summative activities appropriate to the sub- } \\
\text { ject and destination for each course }\end{array}$ & $\begin{array}{l}\text { - introduction of Grade } 11 \\
\text { - curriculum from consortium } \\
\text { - } \text { in-service for administrators } \\
\text { - staff in-services for AER } \\
\text { - Brochures\# } 1 \text { - } 3 \\
\text { - Culminating Activities } \\
\text { in-services (Phase VII) } \\
\text { - Subject AER workshops and } \\
\text { in-services } \\
\text { - Exemplar field testing }\end{array}$ & $\begin{array}{l}\text { - report card comments are subject and ex- } \\
\text { - evctation specific } \\
\text { - strategies used to determine the } 70 \% \\
\text { - assessment criteria given with assign- } \\
\text { ments } \\
\text { - use of exemplars } \\
\text { - used to determine the } 70 \% \\
\text { - evaluations used to determine the } 70 \% \text { re- } \\
\text { flect the weightings developed by the } \\
\text { - subject councils } \\
\text { - eulminating activities part of the } 30 \% \\
\text { flect the weightings developed by the } \\
\text { subject councils }\end{array}$ \\
\hline \multirow[t]{2}{*}{$\begin{array}{l}\text { The percentage grade repre- } \\
\text { sents the quality of the stu- } \\
\text { dent's overall achievement of } \\
\text { the expectations for the } \\
\text { course and reflects the corre- } \\
\text { sponding level of achieve- } \\
\text { ment as described in the } \\
\text { Achievement Chart for the } \\
\text { discipline }\end{array}$} & $\begin{array}{c}\text { FULL } \\
\text { IMPLEMENTATION }\end{array}$ & $\begin{array}{l}\text { - assessment and evaluation are monitored sepa- } \\
\text { rately, only evaluation used to determine the } 70 \% \\
\text { diagnostic and formative assessments not used in } \\
\text { determining the } 70 \% \\
\text { - use of the most consistent level of achievement } \\
\text { throughout the course to determine the } 70 \% \\
\text { professional judgement used to determine the } \\
70 \% \text { grade based on most consistent achievement, } \\
\text { with special consideration for the most recent } \\
\text { - identification of key learnings and alignment of } \\
\text { evaluation to emphasize rhese throughout course } \\
\text { in determining the } 70 \% \\
\text { - assessment and evaluation that allows students to } \\
\text { revisit key expectations throughout course to de- } \\
\text { termine most consistent and most recent level of } \\
\text { achievement }\end{array}$ & $\begin{array}{l}\text { - Subject-specific training } \\
\text { - Exemplar field testing } \\
\text { - Phase VIII } \\
\text { - } \text { Prochure \# } 5 \text { in-service } \\
\text { - Subject/departmental plans }\end{array}$ & $\begin{array}{l}\text { - only summative activities used to calcu- } \\
\text { late marks } \\
\text { - summative evaluation includes culminat- } \\
\text { ing activities } \\
\text { - culminating activities reflect the } \\
\text { weightings developed by subject councils } \\
\text { - marks determined using professional } \\
\text { - judgement, not mathematical calculations } \\
\text { learning skills not used to determine } \\
\text { marks } \\
\text { - key learnings identified and evaluations } \\
\text { are based on these and/or overall expec- } \\
\text { tations, not specific expectations }\end{array}$ \\
\hline & CONSOLIDATION & $\begin{array}{l}\text { - review of courses } \\
\text { - identification of areas for personal growth } \\
\text { (Teacher Action Plan/Annual Learning Plan) }\end{array}$ & & $\begin{array}{l}\text { - Grade } 9 \text { curriculum, assessments and } \\
\text { evaluations revised as required }\end{array}$ \\
\hline
\end{tabular}


Hamilton-Wentworth District School Board ASSESSMENT AND EVALUATION IMPLEMENTATION GUIDELINES

\begin{tabular}{|c|c|c|c|c|}
\hline $\begin{array}{c}\text { POLICY } \\
\text { General Policy Statements }\end{array}$ & & $\begin{array}{l}\text { CLASSROOM PRACTICES } \\
\text { Expectations for teachers and students }\end{array}$ & $\begin{array}{l}\text { RESOURCES/ } \\
\text { SUPPORTS }\end{array}$ & INDICATORS \\
\hline \multirow[t]{5}{*}{$\begin{array}{l}\text { Learning Skills } \\
\text { the report card focuses on two } \\
\text { distinct but related aspects of } \\
\text { student achievement: the } \\
\text { achievement of curriculum ex- } \\
\text { pectations and the develop- } \\
\text { ment of learning skills }\end{array}$} & AWARENESS & $\begin{array}{l}\text { - Identification of learning skills } \\
\text { - Guide to Provincial Report Card studied for details on each } \\
\text { learning skill } \\
\text { analysis of expectations to determine how learning skills are } \\
\text { included (certain subject areas only) } \\
\text { - PROGRAM PLANNING AND ASSESSMENT document } \\
\text { studied }\end{array}$ & $\begin{array}{l}\text { - Subject-specific training } \\
\text { - SIT Training, Phases I-III }\end{array}$ & $\begin{array}{l}\text { - new documents in evidence } \\
\text { - SIT team providing PD } \\
\text { Some schools piloting } \\
\text { Provincial Report Card } \\
\text { exploring research and re- } \\
\text { sources }\end{array}$ \\
\hline & $\begin{array}{l}\text { BEGINNING } \\
\text { IMPLEMENTATION }\end{array}$ & $\begin{array}{l}\text { - instruction, practice and feedback are provided to students to } \\
\text { develop learning skills } \\
\text { - students are provided numerous opportunities to demon- } \\
\text { strate their progress and achievement of the learning skills }\end{array}$ & $\begin{array}{l}\text { - Subject-specific workshops } \\
\text { - Phases III - IV } \\
\text { - Report card comment writing } \\
\text { workshop } \\
\text { - Exemplar (Phase V) in-ser- } \\
\text { vices }\end{array}$ & $\begin{array}{l}\text { - using documents and } \\
\text { achievement charts } \\
\text { - general list of key learning } \\
\text { skills being used } \\
\text { - exploring tools to help } \\
\text { assessment of learning skills } \\
\text { identification of learning } \\
\text { skills in assignments }\end{array}$ \\
\hline & $\begin{array}{c}\text { PARTIAL } \\
\text { IMPLEMENTATION }\end{array}$ & $\begin{array}{l}\text { - students are provided meaningful, timely, detailed and con- } \\
\text { tinuous descriptive feedback and information about } \\
\text { strengths and areas in which improvement is needed } \\
\text { - the assessment of learning skills is distinct from and should } \\
\text { not influence the determination of percentage grades apart } \\
\text { from any that may be included as part of a curriculum expec- } \\
\text { tation } \\
\text { - course outlines are developed reflecting assessment of learn- } \\
\text { ing skills separately from curriculum expectations } \\
\text { - use of a variety of assessment strategies for learning skills } \\
\text { criteria for assessment of learning skills are given to students }\end{array}$ & $\begin{array}{l}\text { - in-service for administrators } \\
\text { - staff in-services for AER } \\
\text { - Brochures\# } 1 \text { - } 3 \\
\text { - Culminating Activities in-ser- } \\
\text { vices (Phase VII) } \\
\text { - Subject AER workshops and } \\
\text { in-services } \\
\text { - Exemplar field testing }\end{array}$ & $\begin{array}{l}\text { - learning skills assessed but } \\
\text { not used to determine marks } \\
\text { - learning skills identified and } \\
\text { assess in each assignment } \\
\text { - feedback on learning skills } \\
\text { provided to students } \\
\text { use of consistent standards } \\
\text { for assessment of learning } \\
\text { skills }\end{array}$ \\
\hline & $\begin{array}{c}\text { FULL } \\
\text { IMPLEMENTATION }\end{array}$ & $\begin{array}{l}\text { - incorporate the assessment of learning skills into course } \\
\text { planning } \\
\text { communicate, inform and instruct parents and the wider } \\
\text { community on the meaning, importance and development of } \\
\text { learning skills } \\
\text { - use of separate tools to evaluate learning skills (Skills Pass- } \\
\text { port, Skills Inventories) } \\
\text { - identification of industry standards for specific learning } \\
\text { skills and inventories developed to evaluate these skills } \\
\text { - assessment allows students to revisit learning skills through- } \\
\text { out course }\end{array}$ & $\begin{array}{l}\text { - Subject-specific training } \\
\text { - Exemplar field testing } \\
\text { - Phase VIII } \\
\text { - Pilot of Skills Passport } \\
\text { - Phase IX } \\
\text { - Subject/departmental plans }\end{array}$ & $\begin{array}{l}\text { - separate recording of assess- } \\
\text { ments, evaluations and learn- } \\
\text { ing skills } \\
\text { - learning skills not used to de- } \\
\text { termine marks (e.g., no de-- } \\
\text { ductions for late penalties, } \\
\text { materials missing, home- } \\
\text { work, ) } \\
\text { - piloting assessment tools, } \\
\text { Skills Passport, Skills Inven- } \\
\text { tories }\end{array}$ \\
\hline & CONSOLIDATION & $\begin{array}{l}\text { - review of courses } \\
\text { identification of areas for personal growth (Teacher Action } \\
\text { Plan/Annual Learning Plan) }\end{array}$ & & $\begin{array}{l}\text { - Grade } 9 \text { curriculum, assess- } \\
\text { ments and evaluations re- } \\
\text { vised as require }\end{array}$ \\
\hline
\end{tabular}

